\title{
Is it worthwhile to screen patients with type 2 diabetes mellitus for subclinical Cushing's syndrome?
}

\section{Sweta Budyal, Swati Sachin Jadhav, Rajeev Kasaliwal, Hiren Patt, Shruti Khare, Vyankatesh Shivane, Anurag R Lila, Tushar Bandgar and Nalini S Shah}

Department of Endocrinology, Seth G S Medical College and KEM Hospital, Parel, Mumbai, Maharashtra 400012, India

\author{
Correspondence \\ should be addressed \\ to A R Lila \\ Email \\ anuraglila@gmail.com
}

\begin{abstract}
Variable prevalence of subclinical Cushing's syndrome (SCS) has been reported in patients with type 2 diabetes mellitus (T2DM), making the need for screening in this population uncertain. It is unknown if this variability is solely due to study-related methodological differences or a reflection of true differences in ethnic predisposition. The objective of this study is to explore the prevalence of SCS in Asian Indian patients with T2DM. In this prospective single center study conducted in a tertiary care referral center, 993 T2DM outpatients without any discriminatory clinical features (easy bruising, facial plethora, proximal muscle weakness, and/or striae) of hypercortisolism underwent an overnight $1 \mathrm{mg}$ dexamethasone suppression test (ODST). ODST serum cortisol $\geq 1.8 \mu \mathrm{g} / \mathrm{dl}$ was considered positive, and those with positive results were subjected to $48 \mathrm{~h}, 2 \mathrm{mg} / \mathrm{day}$ low dose DST (LDDST). A stepwise evaluation for endogenous hypercortisolism was planned for patients with LDDST serum cortisol $\geq 1.8 \mu \mathrm{g} / \mathrm{dl}$. Patients with positive ODST and negative LDDST were followed up clinically and re-evaluated a year later for the development of clinically evident Cushing's syndrome (CS). In this largest single center study reported to date, we found 37 out of $993(3.72 \%)$ patients had ODST serum cortisol $\geq 1.8 \mu \mathrm{g} / \mathrm{dl}$. None of them had LDDST cortisol $\geq 1.8 \mu \mathrm{g} / \mathrm{dl}$, nor did they develop clinically evident CS over a follow-up period of 1 year. Specificity of ODST for screening of CS was $96.3 \%$ in our cohort. None of the T2DM outpatients in our cohort had SCS, hence cautioning against routine biochemical screening for SCS in this cohort. We suggest screening be based on clinical suspicion only.
\end{abstract}

\section{Key Words}

- subclinical Cushing's syndrome

- type $2 \mathrm{DM}$

- screening

- overnight dexamethasone suppression test

\section{Introduction}

Subclinical Cushing's syndrome (SCS) is defined as autonomous cortisol secretion in patients without typical signs and symptoms of hypercortisolism, as in the classic Cushing's syndrome (CS) (1). Screening for a rare disorder like SCS is conceivably more productive if done in a welltargeted, high-risk cohort. The patients with adrenal incidentalomas represent one such cohort in which the prevalence of SCS is found to be high (5-20\%) (2).
In cognizance of this, the Clinical Guideline Committee of the Endocrine Society has recognized adrenal incidentaloma as a valid indication for the screening of SCS (3). Apart from adrenal incidentalomas, the other high-risk populations that have been targeted for SCS screening are patients with type 2 diabetes mellitus (T2DM), obesity, osteoporosis, and polycystic ovarian syndrome (PCOS) $(4,5,6,7,8)$.

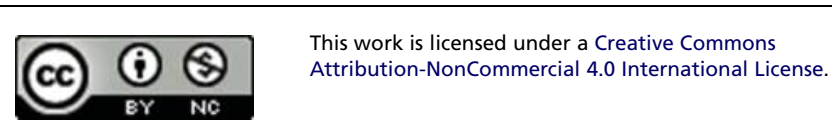


As impaired glucose tolerance and diabetes are important metabolic manifestations of CS, several studies have attempted to examine the prevalence of SCS in T2DM patients. Early detection and alleviation of the duration of adverse metabolic milieu of hypercortisolemic state may be the rationale for undertaking screening of SCS in this cohort. These studies on T2DM patients have reported a varying prevalence ranging from 0 to $9.4 \%(9,10,11,12,13,14,15,16,17,18,19)$. However, these studies are methodologically heterogeneous in terms of sample size, inclusion criteria and screening tests used with various cutoffs that have a bearing on their sensitivity. In addition to these methodological factors, the true difference in prevalence in ethnically different populations might be a concern worth consideration, because most of the previous studies reporting higher prevalence are predominantly from Europe and a few from Japan (10, 11, $12,13,14,15,16,17,18,19)$. In addition, there remains a concern if the reported high prevalence is limited to SCS and not inclusive of previously unappreciated CS.

In the current study, we aimed to find the prevalence of SCS in Asian Indian patients attending a routine T2DM outpatient clinic.

\section{Research design and methods}

\section{Patients}

This was a prospective single center study. The study protocol was approved by the Institutional Ethics Committee and written informed consent was obtained from each participant. A total of 1209 T2DM patients attending the diabetes outpatient clinic were screened. The patients were clinically examined by a single endocrinologist to exclude discriminatory features of CS. Discriminatory features included easy bruising, facial plethora, proximal muscle weakness, and/or striae (especially if reddish purple and $>1 \mathrm{~cm}$ wide). Patients with a history of exogenous corticosteroid intake, pregnant women, women using oral contraceptive (OC) pills within the last 6 weeks, patients on anti-epileptic drugs or antitubercular medicines, and patients with renal failure (creatinine clearance $<60 \mathrm{ml} / \mathrm{min}$ ) or hepatic failure, depression, and alcoholism were excluded.

\section{Methods}

The selected participants underwent a $1 \mathrm{mg}$ overnight dexamethasone suppression test (ODST) on an outpatient basis. The patients were advised to take two tablets of $0.5 \mathrm{mg}$ of dexamethasone at $2300 \mathrm{~h}$ and the sample for cortisol was collected on the next morning between 0800 and $0900 \mathrm{~h}$. Serum cortisol of $>1.8 \mu \mathrm{g} / \mathrm{dl}(50 \mathrm{nmol} / \mathrm{l})$ was considered abnormal. The patients with abnormal ODST were further evaluated with a $48 \mathrm{~h}, 2 \mathrm{mg}$ low dose DST (LDDST) after a gap of at least 1 week after ODST. LDDST was also performed on an outpatient basis after giving written instructions to the patients. They were advised to take $0.5 \mathrm{mg}$ of dexamethasone tablets at 0900, 1500, 2100, and $0300 \mathrm{~h}$ for 2 consecutive days, and the sample for serum cortisol was collected at $0900 \mathrm{~h}$ on the third day, i.e., $6 \mathrm{~h}$ after the last tablet of dexamethasone. Serum cortisol after LDDST of $\geq 1.8 \mu \mathrm{g} / \mathrm{dl}(50 \mathrm{nmol} / \mathrm{l})$ was considered as abnormal. Tablet counts from the empty strips were checked after ODST and LDDST to ensure the compliance. Patients with abnormal LDDST were planned to be further evaluated as per the protocol, which is depicted in Fig. 1.

\section{Hormonal assays}

Serum cortisol was measured by a solid-phase competitive chemiluminescent enzyme immunoassay (Siemens Healthcare, Erlangen, Germany), with an analytical sensitivity of $0.2 \mu \mathrm{g} / \mathrm{dl}$. The intra- and interassay coefficients of variability $(\mathrm{CV})$ of the cortisol assay were 6.9 and $7.3 \%$ respectively. Adrenocorticotropic hormone was measured by a solid-phase, two-site sequential chemiluminescence assay (Siemens Healthcare). The intra- and interassay CV were 9.6 and $8.8 \%$ respectively.

\section{Statistical analysis}

The statistical analysis was performed using SPSS version 15.0. All the values are expressed as mean \pm s.D. or median \pm interquartile range, if the data is not normally distributed. Normality of the data was tested using the Kolmogorov-Smirnov test. Continuous variables were compared using the unpaired t-test or Mann-Whitney $U$ test as appropriate. Categorical variables were compared by a $\chi^{2}$ test. The level of significance was set at $P \leq 0.05$. Sample size was calculated on the basis of the results of previous studies. It is estimated that $\sim 381$ patients would be required to be studied to provide an $80 \%$ chance (beta) of detecting the prevalence rate of SCS of $1 \%$, taking the level of significance as $0.05(\alpha)$.

\section{Results}

As depicted in Fig. 2, 1209 patients were screened; 216 patients were excluded due to various reasons. Nine cases

This work is licensed under a Creative Commons Attribution-NonCommercial 4.0 International License. 


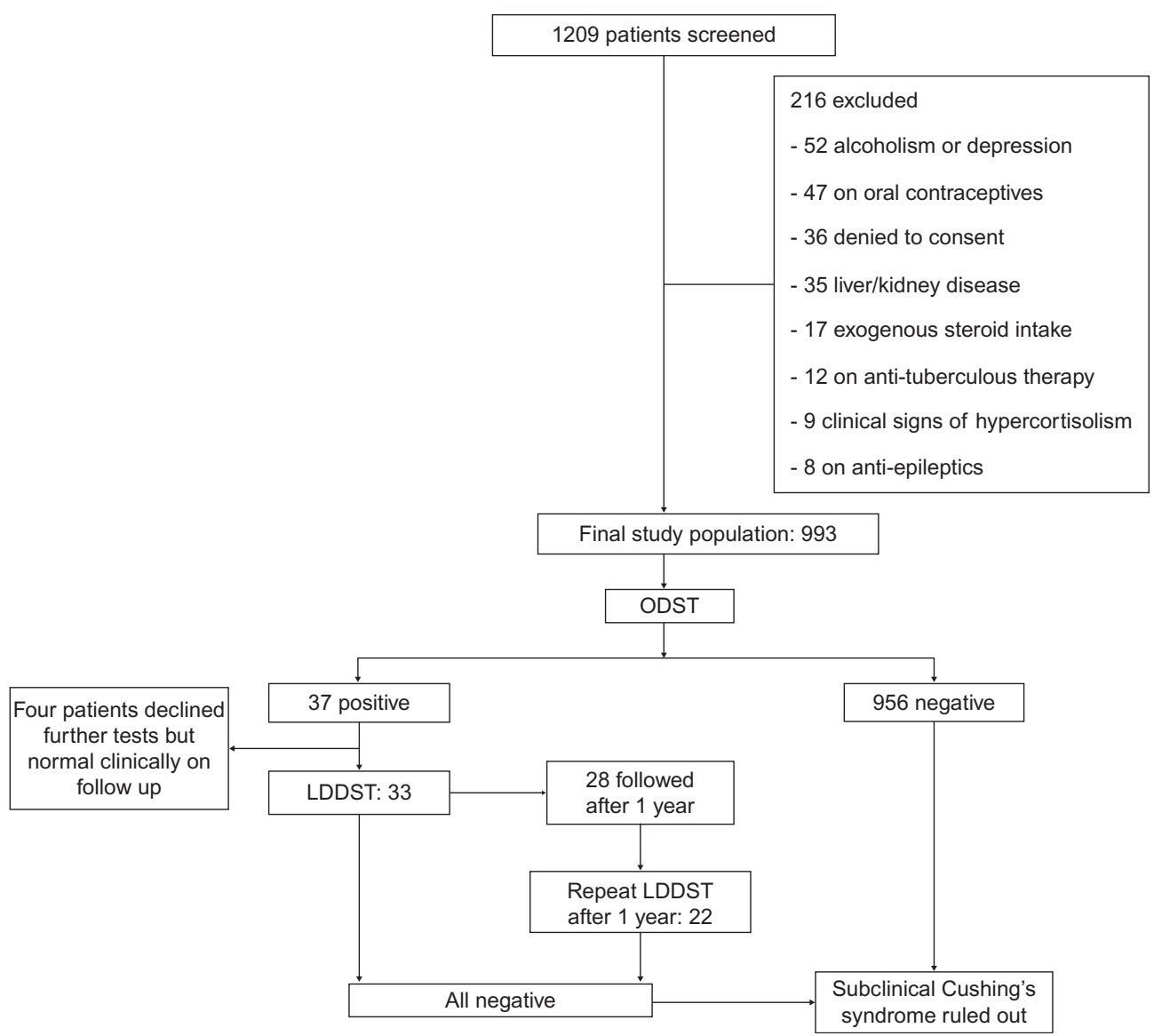

Figure 1

Flowchart of patients evaluated in the study.

had clinical signs of hypercortisolism; hence, they were excluded from the above cohort for SCS screening. Finally, 993 patients were included in the study.

The baseline characteristics of these patients are shown in Table 1. Out of 993 patients, 523 (52.67\%) were females and 470 (47.33\%) were males. The mean age ( \pm s.D.) of the patients was $55.1( \pm 10.58)$ years. The mean ( \pm s.D.) duration of diabetes was $82( \pm 76.38)$ months. The mean HbA1c $( \pm$ s.D. $)$ at the time of study inclusion was $7.84 \%( \pm 1.55)$. In our cohort, the mean BMI was $25.6 \mathrm{~kg} / \mathrm{m}^{2}$ and the relative distribution of patients in various BMI categories, i.e., <23, 23-24.9, 25-29.9, $30-34.9$, and $\geq 35 \mathrm{~kg} / \mathrm{m}^{2}$, was $28,19,39,11$, and $3 \%$ respectively. The mean $\mathrm{HbA} 1 \mathrm{c}$ was $7.84 \%$ and the relative distribution of patients in various $\mathrm{HbA} 1 \mathrm{c}$ categories, i.e., $<6,6-6.9,7-7.9,8-8.9,9-9.9$, and $\geq 10 \%$, was $5,25,32$, 21,9 , and $8 \%$ respectively. In the study population, $53.24 \%$ of the patients had BMI $\geq 25 \mathrm{~kg} / \mathrm{m}^{2}, 55.38 \%$ of the patients had HbA1c $\geq 7.5 \%$ and $46.16 \%$ of the patients satisfied both of these criteria. Hypertension was present in $45.66 \%$ of the study population.

Thirty seven (3.72\%) out of 993 diabetic patients had serum cortisol $\geq 1.8 \mu \mathrm{g} / \mathrm{dl}$ (50 nmol/l) on ODST. The mean serum cortisol of these 37 patients was $2.5 \pm 0.98 \mu \mathrm{g} / \mathrm{dl}$. Only one patient had ODST cortisol of more than $5 \mu \mathrm{g} / \mathrm{dl}$ $(7.1 \mu \mathrm{g} / \mathrm{dl})$. Of these 37 patients, 15 (40.54\%) were females and 22 (59.46\%) were males. The ODST suppressors had no significantly different baseline characteristics than the non-suppressors (Table 2).

Thirty-seven patients who failed to suppress serum cortisol to $<1.8 \mu \mathrm{g} / \mathrm{dl}$ on ODST were subjected to further evaluation. Of these, four patients refused further investigations but continue to remain clinically normal on follow-up in the diabetes clinic. The remaining 33 patients underwent a $2 \mathrm{mg}$ LDDST. None of these patients had cortisol value $\geq 1.8 \mu \mathrm{g} / \mathrm{dl}(50 \mathrm{nmol} / \mathrm{l})$ after LDDST. Out of

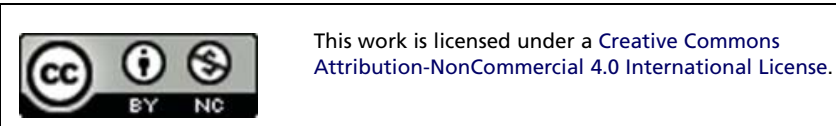




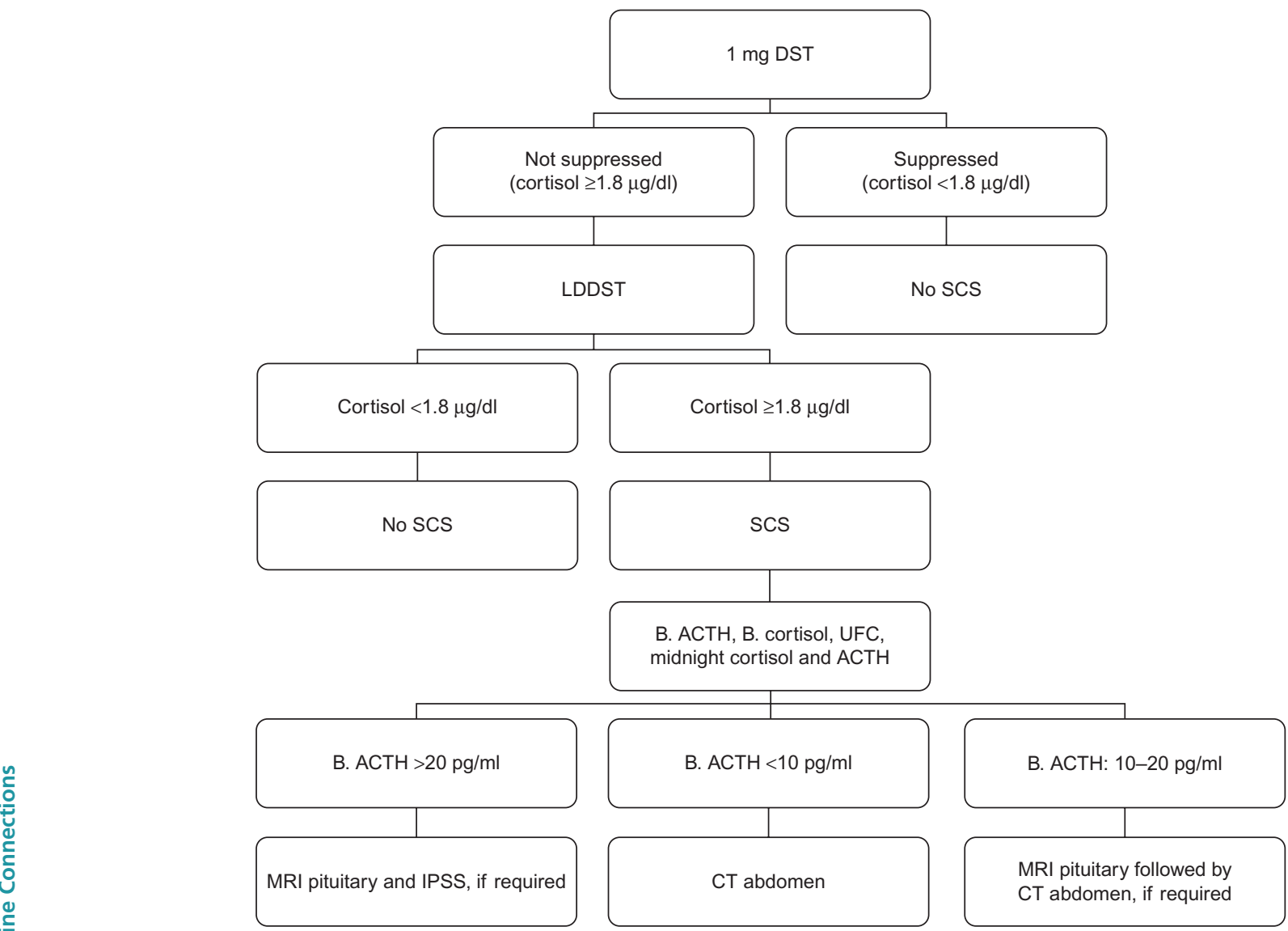

Figure 2

Flowchart for screening of patients for subclinical Cushing's syndrome.

these 33 patients, five were lost to follow-up and the remaining 28 were followed for a period of 1 year. However, none of these patients demonstrated any appearance of Cushingoid features. A repeat LDDST was done in 22 out of 28 patients who were followed up and it was $<1.8 \mu \mathrm{g} / \mathrm{dl}$ in all of them (Fig. 2). Therefore, none of the patients in our cohort had SCS accounting for 0\% prevalence.

The nine patients who had clinical features of CS and who were excluded, as per the study protocol, were evaluated for CS as per routine clinical care. Two of the nine cases were diagnosed as CS and underwent transsphenoidal adenomectomy (histopathologically proven), while the remaining seven did not have endogenous hypercortisolism (ODST cortisol $<1.8 \mu \mathrm{g} / \mathrm{dl}$ ). If these clinically suspicious cases are added to the present study cohort, the prevalence of CS in our T2DM cohort is $2 / 1002(0.2 \%)$.

\section{Discussion}

In our cohort of 993 patients with T2DM, who were not preselected for high risk metabolic characteristics, the prevalence of SCS was $0 \%$. However, it is worth mentioning that SCS could not be ruled out with certainty in four patients with abnormal ODST who refused further evaluation, although they remained clinically normal over a follow-up of 1 year. Additionally, 216 patients who had confounding factors for false positive ODST (e.g., oral contraceptive pills (OCP) use, pregnancy, antiepileptic use, anti-tubercular use, depression, and alcoholism) were also excluded at baseline.

The prevalence of SCS in patients with T2DM in different studies has been variable and has ranged from 0 to $9.4 \%(9,10,11,12,13,14,15,16,17,18,19)$. These studies are heterogeneous in terms of sample size, inclusion criteria and the use of screening tests with

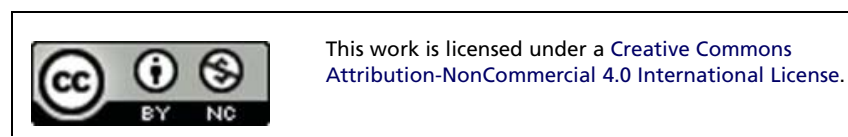


Table 1 Baseline characteristics of patients.

\begin{tabular}{lc}
\hline Variables & \\
\cline { 1 - 2 } Mean age ( \pm s.D.) (range) (years) & $55.1 \pm 10.58(25-87)$ \\
Males/females & $470 / 523$ \\
Duration of diabetes (months) & $82 \pm 76.38$ \\
HbA1c $(\%)$ & $7.84 \pm 1.55$ \\
Mean BMI $\left(\mathrm{kg} / \mathrm{m}^{2}\right)$ & 25.6 \\
Percentage of patients with & 53.25 \\
$\quad$ BMI $>5 \mathrm{~kg} / \mathrm{m}^{2}(\%)$ & 45.66 \\
Hypertension $(\mathrm{HTN})(\%)$ & 1.38 \\
Mean no. of antihypertensive & \\
$\quad$ medications & \\
Antidiabetic medications (\%) & 84.04 \\
Oral hypoglycemic drugs & 4.08 \\
Insulin & 11.88 \\
Oral hypoglycemic drugs + insulin & \\
\hline
\end{tabular}

varying cutoffs. It is not known if the variable prevalence is solely due to methodological differences in these studies or a reflection of true differences in ethnic predisposition. Hence, we attempted to study the prevalence of SCS in T2DM outpatients, taking into consideration each of these factors.

For statistical calculation, considering a prevalence of SCS of $1 \%$, at maximum permissible $\beta$ error of $20 \%$ and at a level of significance (0.05), the minimum sample size required is $\sim 381$ patients (14). Previous studies have sample sizes ranging from 77 to 294 patients with the exception of Terzolo et al. (14) who studied 813 patients in a multicenter setting. To the best of our knowledge, with 993 patients, ours is the largest single center study reported to date. This sample size reduced the beta error (false negative) to as low as 6\%, signifying that the study is adequately powered to account for such a negative result.

Most studies have selected the patients on the basis of higher BMI, higher HbA1c, the presence of hypertension or involved hospitalized patients $(9,10,11,16,18,19)$. Such features are known to be associated with hypercortisolism in the absence of CS and a false positive DST (3). Inclusion of such a high risk cohort increases the pretest probability and introduces a selection bias. We have not preselected our participants for more severe metabolic characteristics. However, $53.24 \%$ of our patients had BMI $\geq 25 \mathrm{~kg} / \mathrm{m}^{2}, 55.38 \%$ of the patients had HbA1c $\geq 7.5 \%$, and $46.16 \%$ of the patients had both of these, while $45.66 \%$ were hypertensive. Thus, our cohort had a fair representation of patients spanning the entire spectrum of severity of metabolic syndrome, eliminating a selection bias. Our approach of no preselection was similar to Reimondo et al. who studied 100 consecutive newly detected diabetic patients without preselection for obesity or poor metabolic control and found one patient with SCS (12). Because the prevalence of adrenal incidentaloma and, hence, SCS increases with age, mean age of the population studied is an important determinant. Our cohort had relatively younger patients (mean age of 55.1 years) as compared to the other studies (mean age ranging from 58.6 to 61 years) (Table 3$)(9,10,11,12,13,14,15)$, which might partly account for the poor yield of SCS observed in our study. However, $15 \%$ of our patients (149 patients) were more than 65 years of age.

For screening a rare disorder like CS, employing an appropriate screening test with good sensitivity at the selected cutoff is of utmost importance. Most previous studies have used $1 \mathrm{mg}$ DST (ODST) as a screening test (Table 3) while a few have used late-night salivary cortisol (LNSC) $(15,16,17)$ or midnight serum cortisol $(18,19)$. However, LNSC has been proposed to be inferior to ODST in an evaluation of SCS in patients with adrenal incidentalomas $(20,21)$. Midnight serum cortisol has poor specificity at a cutoff optimized for an acceptable sensitivity, making it unsuitable as a screening test (22). Across the studies, ODST has been used with different diagnostic cutoffs (varying from 1.8 to $5 \mu \mathrm{g} / \mathrm{dl}$; Table 3). Terzolo et al. found a low prevalence of $0.7 \%$ using an ODST cutoff of $5 \mu \mathrm{g} / \mathrm{dl}$ and cautioned against the screening for SCS in their T2DM cohort, although they had acknowledged the possibility of missing some cases due to a higher cutoff (14). We have used a sensitive cutoff of $1.8 \mu \mathrm{g} / \mathrm{dl}$ to ensure not to miss any cases. Yet, we found zero prevalence of SCS in our cohort thus further substantiating the caution for poor yield of such screening attempts.

Table 2 Comparison of patients with $1 \mathrm{mg}$ ODST cortisol suppressors and non-suppressors.

\begin{tabular}{|c|c|c|c|}
\hline Variables & $\begin{array}{c}\text { ODST } \\
\geq 1.8 \mu \mathrm{g} / \mathrm{dl}\end{array}$ & $\begin{array}{c}\text { ODST } \\
<1.8 \mu \mathbf{g} / \mathbf{d l}\end{array}$ & $P$ value \\
\hline Age (years) & $58 \pm 19.25$ & $55 \pm 15$ & 0.46 \\
\hline $\operatorname{Sex}(M / F)$ & $22 / 15$ & $448 / 508$ & 0.94 \\
\hline BMI $\left(\mathrm{kg} / \mathrm{m}^{2}\right)$ & $25.1 \pm 5.63$ & $25.2 \pm 5.20$ & 0.18 \\
\hline $\begin{array}{l}\text { Duration of diabetes } \\
\text { (months) }\end{array}$ & $72 \pm 97.5$ & $60 \pm 96$ & 0.61 \\
\hline HbA1c (\%) & $\begin{array}{l}7.55 \pm 1.32 \\
(59 \pm 14.4)\end{array}$ & $\begin{array}{l}7.5 \pm 2.4 \\
(58 \pm 26.2)\end{array}$ & 0.52 \\
\hline \multicolumn{4}{|l|}{ Diabetes treatment $(\%)$} \\
\hline $\mathrm{OHA}$ & 86.84 & 83.93 & 1.00 \\
\hline Insulin & 2.63 & 4.15 & 0.99 \\
\hline $\mathrm{OHA}+$ insulin & 10.63 & 11.92 & 0.98 \\
\hline Hypertension (\%) & 60.52 & 45.07 & 0.38 \\
\hline $\begin{array}{l}\text { Need of }>1 \\
\quad \text { anti-hypertensives (\%) }\end{array}$ & 28.94 & 16.16 & 0.38 \\
\hline
\end{tabular}


Table 3 The studies using ODST as a primary screening test in T2DM patients.

\begin{tabular}{|c|c|c|c|c|c|c|c|c|}
\hline References & Region & $\begin{array}{l}\text { Sample } \\
\text { size }\end{array}$ & Cutoff of ODST & Inclusion criteria & $\begin{array}{l}\text { Mean age } \\
\pm \text { s.D. (Years) } \\
\quad \text { (Range) }\end{array}$ & $\begin{array}{l}\text { Percentage } \\
\text { of SCS }\end{array}$ & $\begin{array}{c}\text { Pituitary/ } \\
\text { adrenal/ } \\
\text { ectopic } \\
\text { cause }\end{array}$ & $\begin{array}{l}\text { False positivity } \\
\text { (at cutoff, } \mu \mathrm{g} / \mathrm{dl} \text { ) }\end{array}$ \\
\hline (9) & Israel & $90^{\mathrm{a}}$ & $5 \mu \mathrm{g} / \mathrm{dl}(140 \mathrm{nmol} / \mathrm{l})$ & $\begin{array}{c}\mathrm{BMI}>25 \mathrm{~kg} / \mathrm{m}^{2} \text { and } \\
\mathrm{HbA} 1 \mathrm{c}>9 \%\end{array}$ & $\begin{array}{r}53.5 \pm 1.6^{b} \\
(21-78)\end{array}$ & 3.3 & $2 / 1 / 0$ & $1.1 \%(5)$ \\
\hline$(10)$ & France & 200 & $2.1 \mu \mathrm{g} / \mathrm{dl}(60 \mathrm{nmol} / \mathrm{l})$ & $\begin{array}{c}\mathrm{BMI}>25 \mathrm{~kg} / \mathrm{m}^{2} \text { and } \\
\mathrm{HbA} 1 \mathrm{c}>8 \%\end{array}$ & $\begin{array}{c}58.6 \pm 10.7 \\
(22-84)\end{array}$ & $\begin{array}{l}5.5(2 \% \\
\text { definitive })\end{array}$ & $3 / 8 / 0$ & $15 \%(2.1)$ \\
\hline$(11)$ & Italy & 289 & $1.8 \mu \mathrm{g} / \mathrm{dl}(50 \mathrm{nmol} / \mathrm{l})$ & $\begin{array}{c}\text { Age } 30 \text { years, BMI } \\
19-50 \mathrm{~kg} / \mathrm{m}^{2} \\
\text { hospitalized }\end{array}$ & $\begin{array}{c}60.9 \pm 10.2 \\
(30-82)\end{array}$ & 9.4 & $4 / 21 / 2$ & $5.4 \%(1.8)$ \\
\hline (12) & Italy & 99 & $\begin{array}{l}3.98 \mu \mathrm{g} / \mathrm{dl} \\
\quad(110 \mathrm{nmol} / \mathrm{l})\end{array}$ & $\begin{array}{l}\text { Unselected newly } \\
\text { diagnosed } \\
\text { diabetics }\end{array}$ & $\begin{array}{c}61 \text { (median) } \\
(30-87)\end{array}$ & 1 & $1 / 0 / 0$ & $\begin{array}{c}31.3 \%(1.8) \\
4 \%(3.98)\end{array}$ \\
\hline (13) & Australia & 171 & $1.8 \mu \mathrm{g} / \mathrm{dl}(50 \mathrm{nmol} / \mathrm{l})$ & $\mathrm{BMI}>25 \mathrm{~kg} / \mathrm{m}^{2}$ & $60.9(29-81)$ & $<1^{d}$ & $0 / 0 / 0$ & $15.7 \%(1.8)$ \\
\hline (14) & Italy & 813 & $5 \mu \mathrm{g} / \mathrm{dl}(140 \mathrm{nmol} / \mathrm{l})$ & $\mathrm{BMI}>25 \mathrm{~kg} / \mathrm{m}^{2}$ & $\begin{array}{r}58.9 \pm 8.9 \\
(25-70)\end{array}$ & 0.7 & $1 / 5 / 0$ & $\begin{array}{c}21.8 \%(1.8) \\
4.1 \%(5)\end{array}$ \\
\hline Our study & India & 993 & $1.8 \mu \mathrm{g} / \mathrm{dl}(50 \mathrm{nmol} / \mathrm{l})$ & $\begin{array}{l}\text { Unselected T2DM } \\
\text { outpatients }\end{array}$ & $\begin{array}{c}55.1 \pm 10.5 \\
(25-87)\end{array}$ & 0 & $0 / 0 / 0$ & $3.7 \%(1.8)$ \\
\hline
\end{tabular}

Asian Indian patients are more insulin resistant and have more central obesity at a much lower BMI than their western counterparts leading to a high prevalence of T2DM in India $(23,24)$. Considering the huge denominator of the diabetic population in India, one could expect higher prevalence of SCS, had it been an actuality as a rare secondary cause of diabetes. However, despite recruiting a large sample size with good representation of patients with high risk metabolic characteristics, and despite using a sensitive cutoff, we observed a zero prevalence of SCS. This compels us to speculate that SCS is uncommon in our unselected population with T2DM. But even if the nine clinically evident cases were included, the prevalence of CS in our T2DM cohort is $2 / 1002(0.2 \%)$.

Although we did not a priori set out to study it, we found that the specificity of $1 \mathrm{mg}$ ODST at a cutoff of $1.8 \mu \mathrm{g} / \mathrm{dl}$ was much better (96.3\%) in our cohort with a false positivity rate of $3.72 \%$. At this cutoff, the false positivity rate has been reported to be higher in previous studies (5.4-30\%; Table 3) $(11,12,13,14)$. To understand this, we compared the characteristics of ODS suppressors vs non-suppressors in our cohort (Table 2). None of the factors like age, BMI, duration or control of diabetes or hypertension was significantly different between the two groups. This is in contrast with the study by Terzolo et al. (14) in which the non-suppressors had significantly poor glycemic control and higher systolic blood pressure than the suppressors. Whether this adverse metabolic profile of non-suppressors could at least partly account for the high false positive rate in their cohort remains speculative. The presence of multiple and progressive high risk features increase the pretest probability of CS, and the rate of false positivity is expected to increase in such cohort. This is reflected in the study by Giraldi et al., who found a poor specificity of $80.2 \%$ of the ODST (at cutoff of $1.8 \mu \mathrm{g} / \mathrm{dl}$ ) in a population of 4104 patients suspected to have CS due to the presence of multiple suggestive features (22). In our population, the better specificity could partly be because of the absence of such preselection, which further signifies the reliability of ODST to rule out CS in our routine diabetic clinic, if the need be. As compared to ODST, the performance of LDDST was better in our cohort with no false positives in a limited subset of 33 patients who had false positive ODST. However, the number is too small to allow for a valid comparison between relative specificities of the two tests.

The Endocrine Society guidelines for the diagnosis of CS recommended against widespread testing for CS, and our study provides further strengthening evidence for it (3). None of the T2DM outpatients in our cohort had SCS, cautioning against routine biochemical screening for SCS in such cohort. Hence, we suggest screening be based on clinical grounds only in such low risk unselected T2DM cohort. 


\section{Declaration of interest}

The authors declare that there is no conflict of interest that could be perceived as prejudicing the impartiality of the research reported.

\section{Funding}

This research did not receive any specific grant from any funding agency in the public, commercial or not-for-profit sector.

\section{References}

1 Young WF Jr. The incidentally discovered adrenal mass. New England Journal of Medicine 2007356 601-610. (doi:10.1056/NEJMcp065470)

2 Terzolo M, Bovio S, Pia A, Osella G, Borretta G, Angeli A \& Reimondo G. Subclinical Cushing's syndrome. Arquivos Brasileiros de Endocrinologia e Metabologia 2007 51/8 1272-1279. (doi:10.1590/S0004-27302007 000800013)

3 Nieman LK, Biller BM, Findling JW, Newell-Price J, Savage MO, Stewart PM \& Montori VM. The diagnosis of Cushing's syndrome: an Endocrine Society clinical practice guidelines. Journal of Clinical Endocrinology and Metabolism 200893 1526-1540. (doi:10.1210/jc. 2008-0125)

4 Ness-Abramof R, Nabriski D, Apovian CM, Niven M, Weiss E, Shapiro MS \& Shenkman L. Overnight dexamethasone suppression test: a reliable screen for Cushing's syndrome in the obese. Obesity Research 200210 1217-1221. (doi:10.1038/oby.2002.166)

5 Tiryakioglu O, Ugurlu S, Yalin S, Yirmibescik S, Caglar E, Yetkin DO \& Kadioglu P. Screening for Cushing's syndrome in obese patients. Clinics 201065 9-13. (doi:10.1590/S1807-59322010000100003)

6 Baid SK, Rubino D, Sinaii N, Ramsey S, Frank A \& Nieman LK. Specificity of screening tests for Cushing's syndrome in an overweight and obese population. Journal of Clinical Endocrinology and Metabolism 200994 3857-3864. (doi:10.1210/jc.2008-2766)

7 Chiodini I, Mascia ML, Muscarella S, Battista C, Minisola S, Arosio M, Santini SA, Guglielmi G, Carnevale V \& Scillitani A. Subclinical hypercortisolism among outpatients referred for osteoporosis. Annals of Internal Medicine 2007 147 541-548. (doi:10.7326/0003-4819147-8-200710160-00006)

8 Glintborg D, Henriksen JE, Andersen M, Hagen C, Hangaard J, Rasmussen PE, Schousboe K \& Hermann AP. Prevalence of endocrine diseases and abnormal glucose tolerance tests in 340 Caucasian premenopausal women with hirsutism as the referral diagnosis. Fertility and Sterility 200482 1570-1579. (doi:10.1016/j.fertnstert.2004.06.040)

9 Leibowitz G, Tsur A, Chayen SD, Salameh M, Raz I, Cerasi E \& Gross DJ. Preclinical Cushing's syndrome: an unexpected frequent cause of poor glycemic control in obese diabetic patients. Clinical Endocrinology 1996 44 717-722. (doi:10.1046/j.1365-2265.1996.737558.x)

10 Catargi B, Rigalleau V, Poussin A, Ronci-Chaix N, Bex V, Vergnot V, Gin H, Roger P \& Tabarin A. Occult Cushing's syndrome in type 2 diabetes. Journal of Clinical Endocrinology and Metabolism $2003 \mathbf{8 8}$ 5808-5813. (doi:10.1210/jc.2003-030254)

11 Chiodini I, Torlontano M, Scillitani A, Arosio M, Bacci S, Di Lembo S, Epaminonda P, Augello G, Enrini R, Ambrosi B et al. Association of subclinical hypercortisolism with type 2 diabetes mellitus in a case controlled study in hospitalized patients. European Journal of Endocrinology 2005157 837-847. (doi:10.1530/eje.1.02045)
12 Reimondo G, Pia A, Allasino B, Tassone F, Bovio S, Borretta G, Angeli A $\&$ Terzolo M. Screening of Cushing's syndrome in adult patients with newly diagnosed diabetes mellitus. Clinical Endocrinology 200767 225-229. (doi:10.1111/j.1365-2265.2007.02865.x)

13 Newsome S, Chen K, Hoang J, Wilson JD, Potter JM \& Hickman PE. Cushing's syndrome in a clinic population with diabetes. Internal Medicine Journal 200838 178-182. (doi:10.1111/j.1445-5994.2007. 01434.x)

14 Terzolo M, Reimondo G, Chiodini I, Castello R, Giordano R, Ciccarelli E, Limone P, Crivellaro C, Martinelli I, Montini M et al. Screening of Cushing's syndrome in outpatients with type 2 diabetes: results of a prospective multicentric study in Italy. Journal of Clinical Endocrinology and Metabolism 201297 3467-3475. (doi:10.1210/jc.2012-1323)

15 Liu H, Bravata DM, Cabaccan J, Raff H \& Ryzen E. Elevated late-night salivary cortisol levels in elderly male type 2 diabetic veterans. Clinical Endocrinology 200563 642-649. (doi:10.1111/j.1365-2265.2005.02395.x)

16 Mullan K, Black N, Thiraviaraj A, Bell PM, Burgess C, Hunter SJ, McCance DR, Leslie H, Sheridan B \& Atkinson AB. Is there value in routine screening for Cushing's syndrome in patients with diabetes? Journal of Clinical Endocrinology and Metabolism 201095 2262-2265. (doi:10.1210/jc.2009-2453)

17 Caetano MS, Silva Rdo C \& Kater CE. Increased diagnostic probability of subclinical Cushing's syndrome in a population sample of overweight adult patients with type 2 diabetes mellitus. Arquivos Brasileiros de Endocrinologia e Metabologia 200751 1118-1127. (doi:10.1590/S000427302007000700015)

18 Taniguchi T, Hamasaki A \& Okamoto M. Subclinical hypercortisolism in hospitalized patients with type 2 diabetes mellitus. Endocrine Journal 200855 429-432. (doi:10.1507/endocrj.K07E-045)

19 Murakami H, Nigawara T, Sakihara S, Kageyama K, Yamashita M, Matsuki K, Tanabe J, Matsui J, Tamasawa N \& Suda T. The frequency of type 2 diabetic patients who meet the endocrinological criteria of subclinical Cushing's disease. Endocrine Journal 201057 267-272. (doi:10.1507/endocrj.K09E-352)

20 Raff $\mathrm{H}$. Update on late-night salivary cortisol for the diagnosis of Cushing's syndrome: methodological considerations. Endocrine 2013 44 346-349. (doi:10.1007/s12020-013-0013-0)

21 Masserini B, Morelli V, Bergamaschi S, Ermetici F, Eller-Vainicher C, Barbieri AM, Maffini MA, Scillitani A, Ambrosi B, Beck-Peccoz P et al. The limited role of midnight salivary cortisol levels in the diagnosis of subclinical hypercortisolism in patients with adrenal incidentaloma. European Journal of Endocrinology 2009160 87-92. (doi:10.1530/ EJE-08-0485)

22 Giraldi PF, Ambrogio AG, De Martin M, Fatti LM, Scacchi M \& Cavagnini F. Specificity of first-line tests for the diagnosis of Cushing's syndrome: assessment in a large series. Journal of Clinical Endocrinology and Metabolism 200792 4123-4129. (doi:10.1210/jc.2007-0596)

23 Banerji MA, Faridi N, Atluri R, Chaiken RL \& Lebovitz HE. Body composition, visceral fat, leptin and insulin resistance in Asian Indian men. Journal of Clinical Endocrinology and Metabolism 199984 137-144. (doi:10.1210/jcem.84.1.5371)

24 Misra A, Chowbey P, Makkar BM, Vikram NK, Wasir JS, Chadha D, Joshi SR, Sadikot S, Gupta R, Gulati S et al. Consensus statement for diagnosis of obesity, abdominal obesity and the metabolic syndrome for Asian Indians and recommendations for physical activity, medical and surgical management. Journal of the Association of Physicians of India 200957 163-170.

Received in final form 19 September 2015

Accepted 28 September 2015 http://www.endocrineconnections.org DOI: 10.1530/EC-15-0078
(C) 2015 The authors Published by Bioscientifica Ltd.
This work is licensed under a Creative Commons Attribution-NonCommercial 4.0 International License. 